\title{
Dominium and The Empire of Laws
}

\section{Fenner L. Stewart*}

Civic republicanism endorses a freedom ideology that can support the corporate social responsibility movement [CSR] in some of the challenges it faces. This article is a call for CSR to embrace this normative guidance as a superior alternative to mainstream liberalism. Part I is the introduction. Part II discusses the institutional changes that gave rise to CSR's present incarnation. Part III builds upon this discussion, explaining how corporate risk management strategies pose a threat to CSR's persuasive authority today. It then considers CSR's options for enhancing governance when such persuasive authority is not available. It determines that inspiring integrity - above all else - is integral to success and that, in turn, the removal of moral distance is key to inspiring such integrity. It also notes that whether a form of coercive authority exists or not to back a governance mechanism, the removal of moral distance will be key to its effectiveness. Part IV notes that efforts to remove moral distance have been attempted since the 1970s, but time has proven that business actors have been resilient to meaningful change. It argues that this failure to reduce moral distance is, in part, the result of mainstream liberalism, which continues to nullify such efforts to make business actors feel more accountable for the impacts of their decision-making. It then explores liberalism, detangling the meaning of possibly the most contested, and normatively powerful, concept from the twentieth century to the present. Part $V$ explains civic republicanism. It then explores civic republicanism's conceptual proximity to liberalism. Part VI makes the case for why civic republicanism ought to amend the liberal message, recasting the rights and responsibilities of both imperium (that is, the authority of the sovereign) and dominium (that is, the private authority usually emanating from property and contract) within society. Part VII concludes with a short reflection on the ground covered.

Le républicanisme civique souscrit à une idéologie de liberté qui peut soutenir le mouvement en faveur de la responsabilité sociale de l'entreprise dans certaines difficultés qu'il affronte. Cet article exhorte le mouvement en question à adopter cette orientation normative, présenté comme une avenue supérieure au libéralisme traditionnel. La deuxième partie de l'article traite des changements institutionnels qui ont donné naissance à l'actuelle incarnation du mouvement en faveur de la responsabilité sociale de l'entreprise. La troisième partie de l'article approfondit le débat en expliquant comment les stratégies de gestion des risques des entreprises constituent de nos jours une menace pour la force de persuasion du mouvement en faveur de la responsabilité sociale de l'entreprise. On se penche ensuite sur les options qui s'offrent au mouvement pour renforcer la gouvernance lorsqu'il est privé de pouvoir de persuasion. On conclut qu'insuffler le désir d'intégrité - par-dessus tout - est capital pour la réussite et que l'abolition de la distance morale est, pour sa part, la clé du désir d'intégrité. En outre, qu'un mécanisme de gouvernance soit soutenu ou non par une autorité coercitive,

Fenner Stewart is an Associate Professor in the Faculty of Law at the University of Calgary. Thanks to Cristie Ford, Philip Pettit, Scott Carriere, Chelsea Daku, Austin Beck and Drew Yewchuk for their insights. 
l'abolition de la distance morale sera la clé de l'utilité de ce mécanisme, souligne-t-on. Dans la quatrième partie de l'article, on fait remarquer qu'on tente depuis les années 70 d'abolir la distance morale mais le temps a démontré que les acteurs des milieux d'affaires résistent à un véritable changement. L'auteur soutient que l'échec de ces tentatives est en partie le résultat du libéralisme traditionnel, qui continue de rendre vains les efforts visant à donner aux acteurs des milieux d'affaires le sens de leur responsabilité dans les répercussions de leurs décisions. L'auteur se penche ensuite sur le libéralisme pour démêler la signification de ce qui est peut-être le concept le plus contesté et le plus puissant sur le plan normatif depuis le XXe siècle jusqu'à ce jour. Dans la cinquième partie de l'article, il explique ce qu'est le républicanisme civique, puis on se penche sur la proximité de ce concept avec le libéralisme. Dans la sixième partie, il fait valoir pourquoi le républicanisme civique devrait corriger le message libéral et redéfinir les droits et responsabilités qui se rattachent à l'imperium (le pouvoir du souverain) et au dominium (le pouvoir privé émanant habituellement de la propriété et d'un contrat) dans la société. La septième partie conclut l'article par une brève réflexion sur la matière couverte.

\section{INTRODUCTION}

Sir Edward Coke (1552-1634) was an English jurist, judge, and politician. He revitalized the Magna Carta as a tool of British governance in the seventeenth century, interpreting it to provide a complicated balance between common law and royal prerogative. ${ }^{1}$ Although Coke envisioned that the king would guide the exercise of legal power, protecting against its misuse, he also asserted that English constitutionalism restrained monarchial power, as he believed all power should be subject to judicial review. ${ }^{2}$ Coke's opinions led to a complex relationship with King James I, who considered himself a king by divine right, but who also enjoyed "intellectual debate." ${ }^{3}$ Coke's views proved to be a mixed bag: not only facilitating his ascent to chief justice of the King's Bench but also resulting in his imprisonment. ${ }^{4}$ King James' son, Charles I, held similar views to his father about the source of his authority but was far less interested "in discussing his prerogatives with his subjects." ${ }^{5}$ Charles' hard line led to the English Civil War and his execution in $1649 .{ }^{6}$

The execution of Charles I amplified a debate as to how England ought to be governed. Quentin Skinner argues that two rival schools of thought emerged. ${ }^{7}$ Both sides agreed that the governing authority should primarily "respect and preserve the liberty" of its citizens. ${ }^{8}$ However, opinions split around how this goal ought to be accomplished. ${ }^{9}$ One side asserted that the governing authority ought to ensure citizens did "not suffer any unjust or unnecessary interference in the pursuit of their chosen goals." ${ }^{10}$ This opinion would

1 David Chan Smith, Sir Edward Coke and the Reformation of the Laws: Religion, Politics and Jurisprudence, 1578-1616 (Cambridge, UK: Cambridge University Press, 2016) at 8-10.

$2 \quad$ Ibid at 11.

3 Carolyn Harris, Magna Carta and Its Gifts to Canada: Democracy, Law and Human Rights (Toronto: Dundurn, 2015) at 66.

4 Ibid.

5 Ibid

6 David Cressy, Charles I and the People of England (Oxford: Oxford University Press, 2015) at 7.

7 Quentin Skinner, Liberty before Liberalism (Cambridge UK: Cambridge University Press 1998) at 1-16.

$8 \quad$ Ibid at 119.

9 Ibid.

10 Ibid. 
contribute to the development of liberalism. ${ }^{11}$ The other side argued that the goal of non-interference would never be "sufficient" to ensure liberty and that the government would need to intervene, imposing its law to prevent the arbitrary exercise of power within the governance of "common life." 12 This latter position was inspired by the writing of the Roman historian Titus Livius, whose work recounted the rise of "civitas libera" (that is, free cities). ${ }^{13}$ The citizens of these free cities liberated themselves from monarchial rule and established governments based upon the principles of democracy, equality of citizens, and the authority of law over any person or group of people. ${ }^{14}$ Skinner calls the endorsers of this view "neo-roman theorists." 15

Skinner's interpretation of this English neo-roman theory has inspired prominent legal and political theorists, including James Tully, ${ }^{16}$ Philip Pettit, ${ }^{17}$ and Cristie Ford. ${ }^{18}$ Tully asserts that Skinner's interpretation leads one to appreciate that theories of freedom fall into one of three basic forms: those endorsing "non-interference," those endorsing "positive freedom," and those endorsing freedom "as nondomination." 19 The last theory has been "marginalised by the ascendancy of liberalism." 20 Endorsing this third theory of freedom, Pettit has developed a theory for government action called "civic republicanism." ${ }^{21}$ It argues that government ought to protect its citizens by enacting "good laws." ${ }^{22}$ Laws are good if they champion freedom as non-domination, meaning the exercise of non-arbitrary "imperium" (that is, the authority of the sovereign) to prevent the arbitrary exercise of "dominium" (that is, the private authority usually emanating from property and contract). ${ }^{23}$ In this way, civic republicanism echoes the thought of the neo-roman theorists, who argued that a free society had to be governed by "an empire of laws, and not of men." 24

Ford has imported the political theory of civic republicanism into legal scholarship, endorsing it as a prudent normative guide for the development of modern regulatory theory. ${ }^{25}$ To do so, today's regulatory architects are encouraged to embrace the need to "notice whether a playing field is level in multiple senses" and to ensure that "structural regulatory choices" promote the protection of the "public interest in

11 James Tully, Public Philosophy in a New Key, volume 1: Democracy and Civic Freedom (Cambridge: Cambridge University Press 2008) at 36 [Tully, Public Philosophy].

12 Skinner, supra note 7 at 119.

13 Ibid at 44-45.

14 Ibid.

15 Ibid at 17.

16 Tully, Public Philosophy, supra note 11 at 36, 55, 141, 161-162; see also James Tully, "Political Philosophy as a Critical Activity" (2002) 30 Political Theory 533.

17 José Luis Martí \& Philip Pettit, A Political Philosophy in Public Life Civic Republicanism in Zapatero's Spain (Princeton, NJ: Princeton University Press, 2010) at 31; see also Philip Pettit, "The Freedom of the City: A Republican Ideal" in A Hamlin \& Philip Pettit, eds, The Good Polity (Oxford: Blackwell, 1989) 141; Philip Pettit, "Liberalism and Republicanism" (1993) 28 Australian J Political Science 162; Philip Pettit, "Negative Liberty, Liberal and Republican" (1993) 1 European J Philosophy 15; Philip Pettit, Republicanism: A Theory of Freedom and Government (Oxford: Clarendon Press, 1997) [Pettit, Republicanism].

18 Cristie Ford, Innovation and the State: Finance, Regulation, and Justice (Cambridge, UK: Cambridge University Press, 2017) at 77, 87, 89, 99-100, 127-128, 133, 233-34, 237; see also Fenner L Stewart, "Review of Cristie Ford, Innovation and the State, Regulation, and Justice" (2019) 82 Mod L Rev 190, 191-192.

19 Tully, Public Philosophy, supra note 11 at 36.

20 Ibid.

21 Pettit, Republicanism, supra note 17.

22 Ibid at 36.

23 Ibid at $31-35$.

24 James Harrington, The Commonwealth of Oceana and A System of Politics (Cambridge, UK: Cambridge University Press, 1992) at 20.

25 Ford, supra note 18 at 77, 87, 89, 99-100, 127-128, 133, 233-34, 237. 
its many forms and guises." ${ }^{.6}$ Properly focused, Ford argues, regulatory architects can become better "attuned to the equality-seeking and justice-oriented priorities that the current political moment" recursively and perpetually demands. ${ }^{27}$

This article explores civic republicanism as a practice of freedom that can support the corporate social responsibility movement [CSR] in some of the challenges it faces. Here, CSR refers to a collection of loosely associated actors, organizations, and associations that exist within civil society (that is, a sector of society that is neither industry nor the state). ${ }^{28}$ CSR's main goal is to engage in various state and non-state regulatory processes as it attempts to steer social actors towards targeted ends. CSR has had a difficult relationship with governments because the current ethos of non-interference has facilitated, and continues to endorse, government retrenchment. ${ }^{29}$ This article argues that mainstream liberalism's turn to the right has left some more vulnerable to dominium, allowing powerful private actors (for example, wellcapitalized corporations) to shape social activities to suit their interests. ${ }^{30} \mathrm{CSR}$ has stepped into the role that imperium vacated, protecting those vulnerable to dominium by devising law-like innovations. ${ }^{31}$

This article suggests that such government retrenchment has left some within CSR resentful. ${ }^{32}$ It argues that such bitter feelings, ironically, have left CSR exposed to the lure of "deregulatory politics,"33 encouraging some followers to define CSR as adjacent to, but not part of, the state project, which is now characterized as antithetical to their ends. ${ }^{34}$ By contrast, others place faith in the opportunities that the post-regulatory state presents. ${ }^{35}$ By exploring these opinions, this article will offer an understanding of CSR within the broader normative context of modern regulatory theory.

This article is a call for CSR to embrace the normative guidance of civic republicanism as a superior alternative to mainstream liberalism, offering opportunities for governance to enhance human flourishing. Part II discusses the institutional changes within the modern state project during the twentieth century that gave rise to CSR today. ${ }^{36}$ This part also provides examples of CSR mechanisms to help the reader

$26 \quad$ Ibid at 233 .

27 Ibid.

28 For more detail, see also Michael Edwards, Civil Society, 2nd ed (New York: Polity Press, 2009) at 2-5, 11-14.

29 Fenner L Stewart, "The Corporation, New Governance, and the Power of the Publicization Narrative" (2014) 21 Ind J Global Leg Stud 513 at 519, 524 [Stewart, "Corporation, New Governance"].

30 When this article uses the term "deregulation," it does not mean to remove regulation but, rather, the transfers of regulatory discretion from the regulator to a private actor (usually a business actor) by reforming mandatory rules into discretionary ones. Consider Ibid at 519-523.

31 Vanisha H Sukdeo, Regulation and Inequality at Work: Isolation and Inequality beyond the Regulation of Labour (New York: Routledge, 2019) at 82-83.

32 Consider Ford's observations. See Ford, supra note 18 at 127.

33 William W Bratton, "Enron and the Dark Side of Shareholder Value" (2002) 76 Tul L Rev 1276 at 1278. But see Ford, supra note 18 at 127.

34 See e.g. Sukdeo, supra note 31.

35 See e.g. Ford, supra note 18; Amy J Cohen, "ADR and Some Thoughts on 'the Social' in Contemporary Legal Thought" in Justin Desautels-Stein \& Christopher Tomlins, eds, Searching for Contemporary Legal Thought (Cambridge, UK: Cambridge University Press, 2017) 454 [Cohen, "ADR and Some Thoughts"]; David Levi-Faur, "Regulatory Capitalism and the Reassertion of the Public Interest" (2009) 27 Policy and Society 181 [Levi-Faur, "Regulatory Capitalism"]; Amy J Cohen, "Dispute Systems Design, Neoliberalism, and the Problem of Scale" (2009) 14 Harv Negot L Rev 51 [Cohen, "Dispute Systems Design"]; Colin Scott, "Regulation in the Age of Governance: The Rise of the Post Regulatory State" in Jacint Jordana \& David Levi-Faur, eds, The Politics of Regulation: Institutions and Regulatory Reforms for the Age of Governance (Northampton, MA: Edward Elgar, 2004) 145.

36 Consider Ford, supra note 18 at 12; Sukdeo, supra note 31 at 82-83. For more detail on the operation of reputational capital with governance networks, consider Fenner L Stewart \& Anthony Cioni, "Holistic Security Risk Management 
appreciate what is at issue. Part III builds upon this understanding of CSR, explaining how risk management strategies help business to mitigate the threat to profit that CSR mechanisms pose, while not engaging in the behaviour that CSR aims to inspire. This part then considers CSR's options for enhancing governance, when leveraging coercive authority is not available. In a twist, it determines that coercive authority may be an advantage but that integrity - above all else - is essential to governance success and that the removal of moral distance is key to inspiring such integrity. Part IV notes that efforts to remove moral distance have been attempted since the 1970s, but time has proven that business actors have been resilient to meaningful change. This part argues that humanizing of both decision-making and its impacts have failed to reduce moral distance as hoped because the normative messaging of liberalism continues to nullify such efforts. It then explores liberalism, detangling the meaning of possibly the most contested, and normatively powerful, concept from the twentieth century to the present. Part V then introduces the concept of civic republicanism and explores its proximity to liberalism. Part VI then makes the case for why civic republicanism ought to amend the liberal message, recasting the rights and responsibilities of both imperium and dominium within society. Part VII concludes with a short reflection on the ground covered.

\section{THE LIBERAL SHIFT AND THE RISE OF CSR}

The 1930s to the 1970 s witnessed a tremendous enlargement of the modern state project. ${ }^{37}$ Following the Second World War, Friedrich Hayek protested that the British "progressives" had warped liberalism so radically that it was, in fact, "socialism." 38 He warned that these so-called liberals had carelessly abandoned "the warnings of the great liberal thinkers of the past about the consequences of collectivism." 39 His protests were ignored by serious people, ${ }^{40}$ who were experiencing the post-war zeitgeist - a spirit that brushed aside Sir Winston Churchill for Clement Attlee and his progressive promise of "the New Jerusalem." 41

But, by the mid-1960s, such loose liberal leanings, particularly those of the British left, came under closer scrutiny on both sides of the Atlantic. ${ }^{42}$ The Cold War increased public mistrust of socialism, and

Strategies for E\&Ps: Optimizing Performance by Reducing Surface Risk" (2018) 11 J World Energy L \& Business 48 at 65-74.

37 For detailed on the rise of the welfare state in the Canadian context, see Fenner L Stewart, "Canadian Corporate Governance: A Divergent Path from Other Anglo-American Models?” in Harwell Wells, ed, The Research Handbook on the History of Corporate and Company Law (Northampton, UK: Edward Elgar, 2018) 451 at 462-464. For details on the expansion of the administrative state in the United States, see Robert W Gordon, "Willis's American Counterparts: The Legal Realists' Defence of Administration" (2005) 55 UTLJ 405 at 405-406; see also Thurman W Arnold, The Symbols of Government (New Haven, CT: Yale University Press, 1935); James M Landis, The Administrative Process (New Haven, CT: Yale University Press, 1938); Roscoe Pound, Administrative Law: Its Growth, Procedure and Significance (Pittsburgh: University of Pittsburgh Press, 1942); Adolf A Berle Jr, "Government Function in a Stabilized National Economy" (1943) 33 American Economic Rev 27; Roscoe Pound, “Administrative Law and the Courts” (1944) 24 BUL Rev 201. For its impacts upon liberalism, see Michael Freeden, Liberalism (Oxford: Oxford University Press, 2015) at 47.

38 Friedrich A Hayek, The Road to Serfdom (New York: Routledge, 2001) at 24 [Hayek, Road to Serfdom].

39 Ibid.

40 Daniel Yergin \& Joseph Stanislaw, The Commanding Heights: The Battle for the World Economy (New York: Touchstone, 2002) at 125-126.

41 Kevin Jefferys, The Attlee Governments 1945-1951 (New York: Routledge, 2013) at 4-6.

42 Helena Rosenblatt, The Lost History of Liberalism (Princeton, NJ: Princeton University Press) at 262-264, 271-274; Yergin \& Stanislaw, supra note 40 at $2-18$. 
scandals such as the breaking of the Cambridge Five spy ring quickened the pace. ${ }^{43}$ No longer could academics from the British elite pass off student communists in their hallowed halls as the product of a "fashionable intellectual fad": it was recruiting, it was treason, it was the enemy within! 44 As a result, Attlee-style liberalism was short-lived, paving the way for liberalism's "turn to the right." 45 By the 1960s, Hayek's warnings from the 1940s were seen in a different light. ${ }^{46}$ By the 1970 s, the groundwork was in place for an attack on "big government." ${ }^{7}$ By the 1980s, that groundwork became state practice with the elections of, first, Margaret Thatcher in Britain in 1979, then Ronald Reagan in the United States in 1980, then Brian Mulroney in Canada in $1984 .{ }^{48}$ By the 1990s, this revamped liberalism became known commonly as neo-liberalism. ${ }^{49}$

Commenters are divided over liberalism's turn to the right. Its market focus has been so successful that it has become the "common sense way" people see the world. ${ }^{50}$ Some view this turn as a revival of the classic liberal ideas of the mid-nineteenth century, successfully curtailing government largesse. ${ }^{51}$ Others warn this shift merely re-establishes "the conditions for capital accumulation," which necessitated a rollback of safeguards that ensured a more equitable distribution of wealth within society (that is, government programs that protected the vulnerable, provided progressive taxation, ensured the right to unionize, and so on). ${ }^{52}$ Empirical data reinforces such concerns, establishing that Western governments have weakened or abandoned many such programs, turning the tide against economic equality. ${ }^{53}$

Yet, not all regard this shift in liberalism in such negative terms. For some, the focus on government retrenchment blinds one to the big picture: the transition from government to governance. ${ }^{54}$ David LeviFaur asserts that the "shift away from government" was not a "shift away from the state." 55 The state is more than just government, and as the role of government in governance declined, the role of other organs of the state (for example, courts) expanded. ${ }^{56}$ It also marks a collective acknowledgement in policy circles that government - in particular, the welfare state - failed to be effective, ${ }^{57}$ leading to the conclusion that governments needed help from civil society and regulated actors (for example, business). ${ }^{58}$ Put differently, modern society was not going to run smoothly if government acted as the parent and regulated actors acted as the semi-cooperative children. From this perspective, the goal of dismantling the welfare state was not

43 “Decrypting the Cambridge Five Espionage," The Economist (8 February 2018), online: <www.economist.com/booksand-arts/2018/02/08/decrypting-the-cambridge-five $>$.

44 Ibid.

45 Rosenblatt, supra note 42 at 262-264, 271-274; Yergin \& Stanislaw, supra note 40 at 2-18.

46 Yergin \& Stanislaw, supra note 40 at 2-18.

47 Ibid at 131; but also consider Hayek, Road to Serfdom, supra note 38.

48 Yergin \& Stanislaw, Ibid at 80-81, 130-131.

49 David Harvey, "Neoliberalism as Creative Destruction", (2007) 610 Annals of the American Academy of Politics \& Social Science 22 at 23.

50 Ibid at 23; Harry W Arthurs, "The Administrative State Does to Market (and Cries Wee, Wee, Wee All the Way Home)" (2005) 55 UTLJ 797 at 799.

51 Philip Mirowski \& Dieter Plehwe, The Road from Mont Pèlerin: The Making of the Neoliberal Thought Collective (Cambridge, MA: Harvard University Press, 2009) at 5-6.

52 Harvey, supra note 49 at 29.

53 Thomas Piketty, Capital in the Twenty-First Century (Cambridge, MA: President and Fellow of Harvard College, 2014) at $30-35$.

54 David Levi-Faur, "From 'Big Government' to 'Big Governance'?”' in David Levi-Faur, ed, The Oxford Handbook of Governance (Oxford: Oxford University Press, 2012) 3 at 3 [Levi-Faur, "From Big Governance"].

55 Ibid at 8.

56 Ibid.

57 Ibid.

58 Stewart, “Corporation, New Governance," supra note 29 at 517-533. 
to create a deregulated free-for-all but, rather, to trigger a period of regulatory experimentalism, where new regulatory tools (for example, the CSR's non-state regulatory tools) could be introduced and then calibrated to improve or replace antiquated governance processes. ${ }^{59}$

Empirical data rejects the claim that deregulation occurred, establishing that Western states experienced a spike in regulatory density - not a decline - from the 1980s to the 2000s; as Levi-Faur and Jacint Jordana declare, "[i]f we were to judge neoliberalism by the degree of 'deregulation' it attained, it would be a failure." ${ }^{60}$ However, an increase in regulatory density does not necessarily result in a more effectively regulated environment. ${ }^{61}$ And, yet, this suggestion invites just such a premature presumption (that is, greater density equals greater effectiveness). This result is unfortunate since it is almost certainly false. Evidence points in the opposite direction; it appears quite clear that greater inequality is the hallmark of the last decades of the twentieth century. ${ }^{62}$

Others, such as Ford and Amy Cohen, are still as optimistic as Levi-Faur about this shift from government to governance. ${ }^{63}$ None understand it in the catastrophic terms that, for instance, David Harvey does. ${ }^{64}$ Instead of exposing the economically vulnerable to dominium, Cohen regards this shift as a move towards governance innovation, an evolution from a "power-based and rights-based" dispute resolution platform to an "interest-based" one, which supports plurality within decision-making. ${ }^{65}$ She foresees a less paternalistic governance, which empowers impacted parties to broker solutions of their own design and leads to more "mutually advantageous" resolutions to conflict. ${ }^{66}$ Ford offers a qualified support, noting that safeguards must be in place to ensure impacted parties enjoy bargaining power that is "level in multiple senses." ${ }^{67}$ Cohen is not blind to this need for safeguards either, asserting "lower-power parties" must be supported to secure "better market outcomes than they would otherwise achieve."68

To be clear, successfully neutralizing power asymmetries in society is a very tall order. It is less of a minor tweak to a governance strategy that is destined for success and more of a highly exposed weakness to a governance opportunity that otherwise represents significant potential. In other words, few would disagree that such a governance mechanism would be a huge improvement in governance, if one first assumes that power asymmetries between the impacted parties will not undermine it. However, this assumption represents a formidable if.

In sum, the debates amongst progressive scholars focus upon the motivations for the liberal shift, its effects, and the appropriate response. While some view the liberal shift as a negative (that is, seeing the need to reverse the evils of state retrenchment and deregulation), others are more optimistic (that is, seeing the opportunities for regulatory experimentalism, which can improve upon the institutional designs of the twentieth century).

59 David Levi-Faur \& Jacint Jordana, The Making of a New Regulatory Order (2005) 589 Annals of the American Academy of Politics \& Social Science 6 at 6-7.

60 Ibid at 8.

61 Stewart, “Corporation, New Governance," supra note 29 at 523, 526, 528; Fenner L Stewart, "Behind the Cloak of Corporate Social Responsibility: Safeguards for 'Private' Participation within Institutional Design” (2018) 25 Ind J Global Leg Stud 233 at 244, 256-257 [Stewart, "Behind the Cloak"].

62 See Piketty, supra note 53.

63 See Ford, supra note 18; Levi-Faur, "From Big Governance," supra note 54; Levi-Faur, "Regulatory Capitalism," supra note 35; Cohen, "Dispute Systems Design," supra note 35 at 60; Cohen, "ADR and Some Thoughts," supra note 35 at $456-461$.

64 Harvey, supra note 49 at 29.

65 Cohen, "Dispute Systems Design," supra note 35 at 62.

66 Ibid at 62.

67 Ford, supra note 18 at 233.

68 Cohen, "Dispute Systems Design," supra note 35 at 77. 
Most agree that modern CSR is a response to the shift from government to governance. ${ }^{69}$ This response produced a new breed of regulatory architect, who devised and then employed non-state regulatory tools. ${ }^{70}$ These tools have been successful at leveraging "compliance-enhancing non-legal forces - including community norms, individual morality, and market forces" to create punitive reputational risk mechanisms for policing socially irresponsible behaviour. ${ }^{71}$ An example of one such mechanism is the Global Reporting Initiative. ${ }^{72}$ This non-governmental organization [NGO] recommends standards and best practices for producing sustainability reports (that is, reports by businesses on the economic, environmental, and social impacts of their activities) ${ }^{73}$ When companies are not compelled (that is, by contract or regulation) to issue sustainability reports, they do so voluntarily, which is most often the case. ${ }^{74}$

Why would companies voluntarily subject themselves to such scrutiny? Companies strive to protect their reputations, since companies with good reputations have an easier time producing and selling their wares. ${ }^{75}$ Citizens expect companies to issue sustainability reports. If they fail to do so, they are putting their reputations at risk. To optimize risk management, companies will want to advertise that their sustainability reporting is legitimate. A good way to do so is to ensure that their reporting conforms with the Global Reporting Initiative's standards by complying with all of its reporting requirements. ${ }^{76}$ The $^{2}$ Global Reporting Initiative illustrates how CSR can adopt an educational role. As such, CSR leverages reputational risk to teach companies, industry groups, and governments to operate more ethically. ${ }^{77}$

CSR has also adopted an "institutional contrarian" role. ${ }^{78}$ For instance, a NGO might monitor a regulated space by facilitating third-party auditing, which verifies that industry actors (or governments, for that matter) meet the standards they claim to be meeting. ${ }^{79}$ A good example of such an institutional contrarian is Social Accountability International. ${ }^{80}$ It offers a labour certification program, called Social Accountability $8000 .{ }^{81}$ Social Accountability International has a public certification registry, which lists

69 Levi-Faur, "From Big Governance," supra note 54 at 3-6; Sukdeo, supra note 31 at 82-83, 89, 102-111; Ford, supra note 18 at 126-131; Harwell Wells, "The Cycles of Corporate Social Responsibility: An Historical Retrospective for the Twenty-First Century” (2002) 51 U Kan L Rev 77 at 131-134; Edwards, supra note 28 at 2-5, 11-14.

70 See Wells, supra note 69 at 111-134.

71 Ford, supra note 18 at 12 . For an example of what this might look like in practice, see Stewart \& Cioni, supra note 36 at 65-74.

72 See Global Reporting Initiative, online: <www.globalreporting.org $>$.

73 Ibid.

74 Dessislava Todorova, "Voluntary vs. Mandatory Sustainability Reporting," Global Reporting Initiative (2011), online: $<$ www.globalreporting.org/information/news-and-press-center/Pages/Voluntary-vs-mandatory-sustainability-reporting.aspx>.

75 For more on such risk management theory, see Stewart \& Cioni, supra note 36 at 79-83.

76 Ibid.

77 Cynthia A Williams, "Corporate Social Responsibility and Corporate Governance” in Jeffrey Gordon \& Georg Ringe, eds, Oxford Handbook of Corporate Law and Governance (Oxford: Oxford University Press, 2018) 634 at 635-641.

78 Ford, supra note 18 at 116 . For more on the theory and practice of such risk governance networks, see Stewart \& Cioni, supra note 36 at $65-79$.

79 Ford, supra note 18 at 116. On the development of these standards, see James W Coleman, "Energy Competition: From Commodity to Boutique \& Back" in Klaus Mathis \& Avishalom Tor, eds, New Developments in Competition Law and Economics (Berlin: Springer, 2019) 321 at 322-323.

80 See Social Accountability International, online: $<$ www.sa-intl.org/index.cfm?fuseaction=Page. ViewPage\&pageId=472>.

81 Social Accountability International, "Social Accountability 8000" (June 2014), online: <www.saintl.org/_data/global/files/SA8000Standard2014(3).pdf $>$. 
the companies that participate in Social Accountability 8000 and, by omission, reveals those that do not. ${ }^{82}$ By participating in Social Accountability 8000, companies agree to open their doors to third-party certification auditors, who verify that they are meeting labour standards. ${ }^{83}$

As institutional "contrarians," such NGOs vigilantly monitor regulated spaces in their areas of specialization. ${ }^{84}$ Ensuring public disclosure is a key strategy for leveraging reputational risk, providing companies opportunities to safeguard their goodwill amongst their consumers, while imposing additional uncertainty on those that ignore such CSR certifications. In this way, CSR imposes a "persuasive authority," leveraging reputational risk to enhance governance norms. ${ }^{85}$ Such strategies have been successful, as the public tends to trust civil society actors as "independent" observers (that is, unaffiliated with either government or business). ${ }^{86}$

As a result of such initiatives, CSR has built impressive "multi-scalar" regulated spaces, ${ }^{87}$ which map layers of compliance mechanisms over state regulation. ${ }^{88}$ To illustrate, consider the Task Force on Climate-related Financial Disclosures [CFD Task Force]. It helps to provide information about the climate-related impacts of business activities, the financial implications of climate change, and the risks associated with transitioning to low-carbon economies. ${ }^{89}$ The CFR Task Force lobbies governments to reform their securities regulations so that publicly traded companies will be obliged to issue climaterelated content in their financial disclosures. ${ }^{90}$ When governments agree, it also provides technical advice on how to reform state regulation. ${ }^{91}$ It also encourages companies to develop climate-related disclosures. ${ }^{92}$ Finally, it informs markets by facilitating disclosures that better educate investors and consumers before they participate in market transactions. ${ }^{93}$ In these ways, the CFR Task Force links governments, businesses, investors, and consumers (that is, harmonizes multi-scalar activities through a governance network), enhancing governance function. This regulatory architecture provides a prime example of how CSR has supported the shift from government to governance and, in doing so, has also reconstituted

82 Ibid.

83 Social Accountability International, "Benefits of SA8000 Certification" (2019), online: <www.saintl.org/index.cfm?fuseaction=Page.viewPage\&pageId=1838\&parentID=1689>.

84 Brett McDonnell \& Daniel Schwarcz, "Regulatory Contrarians" (2011) 89 NCL Rev 1629 at 1644-1651; see also Ford, supra note 18 at 116 .

$85 \quad$ Ibid at 1646.

86 Ford, supra note 18 at 116.

87 Ibid at 3.

88 Sukdeo, supra note 31 at $89,141$.

89 Task Force on Climate-related Financial Disclosures (TCFD), "Recommendations of the Task Force on Climate-related Financial Disclosures: Final Report" (June 2017), online: <www.fsb-tcfd.org/wp-content/uploads/2017/06/FINAL-2017TCFD-Report-11052018.pdf>.

90 Green Finance Taskforce, "Accelerating Green Finance: A Report to Government by the Green Finance Taskforce" (March 2018), online:

<assets.publishing.service.gov.uk/government/uploads/system/uploads/attachment_data/file/703816/green-financetaskforce-accelerating-green-finance-report.pdf $>$.

$91 \quad$ Ibid; TCFD, supra note 89.

92 TCFD, supra note 89.

93 Ibid; see also Green Finance Taskforce, supra note 90. Note, however, that companies may often slant their disclosures to send different messages to different audiences. See James W Coleman, "How Cheap Is Corporate Talk? Comparing Companies' Comments on Regulations with Their Securities Disclosures” (2016) 40 Harv Envtl L Rev 47 at $70-75$ (finding that companies tell investors and regulators different things about whether proposed regulations could harm their business). 
today's understanding of public-private governance (that is, how "states, markets, civil society groups, and individuals interact"), challenging long-held notions about the essential elements of law. ${ }^{94}$

\section{CSR'S KEY CHALLENGE}

CSR's mechanisms may not wield the power of the state, but their sanctions have enjoyed some persuasive authority. When CSR exposes the unethical behaviour of business, the reputational damage can threaten profits. ${ }^{95}$ Thus, it follows that for-profit actors, who take reputational risk seriously, also take CSR's mechanisms seriously too. Another presumption is that, after the "constraints of power" have been established (for example, standards enforced by reputational risk), ${ }^{96}$ just being in the "field of visibility" forces conformity. ${ }^{97}$ As a result, companies will abide by CSR mechanisms to avoid reputational harm.

However, unfortunately for CSR, business has also developed other risk mitigation strategies, which can avoid the threats to profit without the cost of complying with CSR mechanisms in some cases. ${ }^{98}$ Inhouse communications specialists have mastered the art of merely appearing ethical to their consumers, while obscuring the fact that their companies have done very little to change their conduct in meaningful ways. ${ }^{99}$ They can polish codes of conduct and associated reports to comply with the expectations of civil society. ${ }^{100}$ They can also engage in a number of clever advertising strategies that cast business activities in the best light, resulting in a similar effect. Such skills in appearing ethical potentially create a "powerful antidote to the negative perceptions of others," which helps to skirt detection and thus facilitates "business as usual." 101

When the cost of complying with CSR's demands is higher than the cost of employing a communications strategy with a similar de-risking effect, some companies will opt for the lower cost option. ${ }^{102}$ This option directly impacts the deterrent effect of CSR mechanisms. To the degree that this problem exists, CSR provides a good measure of how well the business community has experienced a meaningful shift in business ethics. Or, as John Roberts puts it, how much organizational culture has changed from the mindset of "we care what you think of us" to "we care about the effects - economic, social, environmental - that we have upon the communities and countries in which we operate." 103 Roberts suggests that the "we care what you think of us" organizational culture resembles the neo-classical economic construction of self. ${ }^{104}$ This self is "opportunistic" and "self-seeking," viewing social

94 Kerry Rittich, "Functionalism and Formalism: Their Latest Incarnations in Contemporary Development and Governance Debates" (2005) 55 UTLJ 853 at 856; see also Gillian K Hadfield \& Barry R Weingast, "Microfoundations of the Rule of Law" (2014) 17 Annual Rev Political Science 21 at 28-34.

95 Consider Stewart \& Cioni, supra note 36 at 65-79; Williams, supra note 77 at 637-641; Ford, supra note 18 at 116 ; Sukdeo, supra note 31 at 82-83, 89, 102-111. More broadly, see Michel Foucault, Discipline and Punish: The Birth of the Prison, 2nd ed (New York: Vintage Books 1995) at 114, 189, 202, 214.

96 Consider Stewart \& Cioni, supra note 36 at 65-79; Williams, supra note 77 at 637-641; Ford, supra note 18 at 116 ; Sukdeo, supra note 31 at 82-83, 89, 102-111.

97 Foucault, supra note 95 at 114, 189, 202, 214.

98 John Roberts, "The Manufacture of Corporate Social Responsibility: Constructing Corporate Sensibility" (2003) 10 Organization 249 at 251 .

99 Ibid.

100 Ibid at 257.

101 Ibid.

102 Ibid.

103 Ibid at 259.

104 Ibid at 251. 
relationships as "fundamentally competitive."105 It engages in good behaviour because it amounts to a "calculated cooperation when reciprocal self-interests coincide."106

Roberts suggests that "the senses" can "break us out" of this image of self: getting others "under our skin" to make "us always already vulnerable to others' vulnerability" (that is, being aware of others compels compassion). ${ }^{107}$ Roberts is adopting the theory of Emmanuel Levinas, who argues that the process of making the self an ethical being is putting "the soul of the other in me" (that is, opening my concern to the vulnerability of others). ${ }^{108}$ This connection with others creates the "assignation of responsibility" for one's neighbour, spoiling "the plans we have for our own enjoyment." 109 As Roberts notes, we become responsible "despite the self." 110

In application, to get under the skin of business culture, the people within business organizations have to remove the "moral distance" between the actions they take and their effects. ${ }^{111}$ One relevant kind of moral distance might be spatial (for example, the distance between an action in one country and its negative effect in another country). Another might be temporal (for example, the distance between an action by one generation and its negative effect upon a future generation). Yet another might be the distance created by an organizational hierarchy (for example, the distance between one action at the start of a series of actions within a business and its eventual negative effect at the end). Each of these distances creates opportunities for one to remain free from concerns for one's neighbour (that is, from the foundation of a genuine ethical restraint upon the self). ${ }^{112}$

To address moral distance, CSR has attempted to introduce narratives about business action that are "reducible to human stories," helping to ensure that the business organization is seen as a site of significant "human activity." 113 Such humanizing of business actions and their effects helps to remind decisionmakers of the consequences of their choices. ${ }^{114}$ To the more cynical, this knowledge engagement offers little comfort since it represents a thin line of defence against "corporate irresponsibility." 15 Discourse forms an unruly community of ideas, and introducing an idea to it is like adding a species to an ecosystem: the effects will be complex and unpredictable. ${ }^{116}$ So perhaps CSR must live with the ever-present danger

105 Ibid.

106 Ibid.

107 Ibid at 252.

108 Emmanuel Levinas, Otherwise Than Being or Beyond Essence (Dordrecht: Kluwer, 1991) at 100.

109 Roberts, supra note 98 at 252.

110 Ibid at 253.

111 Ibid at 259-261.

112 Ibid at 259.

113 See Mae Kuykendall, "No Imagination: The Marginal Role of Narrative in Corporate Law” (2007) 55 Buff L Rev 537 at 541.

114 See Grimshaw v Ford Motor Company, 119 Cal App 3d 757 (1981); but see Gary T Schwartz, "The Myth of the Ford Pinto Case" (1991) 43 Rutgers L Rev 1013. More broadly, see also Thomas Nagel, Mortal Questions (Cambridge, UK: Cambridge University Press, 1979) at 59; Stewart, “Corporation, New Governance," supra note 29 at 544.

115 Lawrence E Mitchell, Corporate Irresponsibility: America's Newest Export (New Haven, CT: Yale University Press, 2001) at 3-4.

116 See Jean-François Lyotard, The Postmodern Condition: A Report on Knowledge (Manchester: Manchester University Press, 1984) at 26; see also Cornelius Castoriadis, The Imaginary Institution of Society (Cambridge, MA: MIT Press, 1998). For instance, gray wolves were introduced to Yellowstone National Park and lead to a complex and unexpected response by the ecosystem (that is, greater spatial variation in vegetation). See Mack S Boyce, "Wolves for Yellowstone: Dynamics in Time and Space” (2018) 99 J Mammalogy 2021. 
of Oliver Wendell Holmes' "bad man," 117 who will never do more than hide behind his mastery of ethical appearances. ${ }^{118}$ As Holmes warned, one can never assume that the bad man, who never responds to the "vaguer sanctions of conscience," does not exist within a regulated space. ${ }^{119}$ Accordingly, legal institutions must be designed in a manner that ensures regulated actors face "material consequences" when they lack integrity, pursue self-interest in unethical ways, or callously undermine governance mechanisms. ${ }^{120}$

Some might see such a Holmesian stance as representing a lack of faith in the CSR vision that some have for the development of modern governance. ${ }^{121}$ However, building Holmesian safeguards into institutional design does not necessarily represent a lack of faith in CSR, just a fear of mainstream liberalism's turn to the right, which has the power to transform the best institutional design in theory into a "stark utopia" in practice. ${ }^{122}$ It comes down to one issue: can current for-profit organizational culture evolve past an ethics based on a "calculated cooperation when reciprocal self-interests coincide"? ${ }^{123}$ If no, then institutional design without Holmesian safeguards represents a serious risk to the powerless in society. That said, even the most heavy-handed interpretation of Holmes' approach (for example, some form of aggressive command-and-control strategy) will also fall short of success if calculated cooperation is the ceiling for integrity within governance mechanisms. If the agents of governance lack the requisite integrity to put a plan into practice - no matter how perfect on paper - it is doomed to fail. ${ }^{124}$

Thus, even with the coercive power of the state as backstop enforcement, CSR likely would not be able to overcome a lack of integrity. Agents of governance must be good faith actors, especially those with power (whether that be imperium or dominium). Therefore, it matters little whether CSR can prevent forprofit actors from de-risking their regulatory mechanisms without complying with them. Sound governance must be built upon genuine commitment by business to the governance process. The mastery of ethical appearance is a symptom, not the problem. The problem is a business mindset that is capped at calculated cooperation. ${ }^{125}$ One might suggest that scholars, such as Cohen, are not concerned with whether the agents of governance rise above the ethics of calculated cooperation since this level of cooperation is all that is needed for Cohen's "interest-based" platform for governance to be effective. ${ }^{126}$ If calculated cooperation includes an unwavering commitment to the process of governance, then this observation is probably correct. But, if calculated cooperation means unwavering commitment to self-interest (to winning and no more), then this observation is probably incorrect and Cohen's platform is likely to be crushed by the power asymmetries which provide the shortest (and probably most myopic) path to victory over rivals.

117 Oliver Wendell Holmes, "The Path of the Law" (1997) 110 Harv L Rev 991 at 993. For an endorsement of the Holmesian "bad man" when considering business actors, see generally Jill E Fisch, "The 'Bad Man' Goes to Washington: The Effect of Political Influence on Corporate Duty" (2006) 75 Fordham L Rev 1594.

118 Roberts, supra note 98 at 251.

119 Holmes, supra note 117 at 993.

120 Ibid.

121 Roberts, supra note 98.

122 Karl Polanyi, The Great Transformation: The Political and Economic Origins of Our Time, 2nd ed (Boston: Beacon Press, 2001) at 3; see also Harvey, supra note 49 at 23.

123 Roberts, supra note 98 at 251.

124 Cohen, "ADR and Some Thoughts," supra note 35 at 460-461.

125 Roberts, supra note 98 at 251.

126 Cohen, "Dispute Systems Design," supra note 35 at 62. 
In conclusion, to improve ethical standards, CSR and others have constructed narratives, which communicate to business actors the impacts their decisions are having upon the lives of others. ${ }^{127}$ Such messaging is designed in part to reduce moral distance. ${ }^{128}$ Yet, humanizing the impacts of business decisions is not a new practice, ${ }^{129}$ and although improvements have occurred, time has shown that business culture is stubbornly resilient to this strategy. ${ }^{130}$ This resilience inspires some to conclude that business culture generates a pathological pursuit of profit, but this conclusion is unsatisfying. ${ }^{131}$ It offers only a profound punctuation to the issue, leaving little substantive direction for institutional reform. ${ }^{132}$ An alternative conclusion is that more strongly embedded normative messaging is communicating to business actors that they are not truly responsible for the impacts of their decisions or that the impacts are justified. Either way, other messaging is keeping said moral distance in place, legitimating business as usual. This article argues that mainstream liberalism is the culprit.

\section{LIBERALISM}

The last part concluded that the key to success for CSR is inspiring integrity within governance. If Roberts is correct, inspiring integrity requires a strategy to "break" business actors of embracing a selfconception that is resilient to "others" vulnerability." 133 The last part also concluded that such a strategy has been at play for decades, but something is preventing business actors from evolving beyond an ethics of calculated cooperation. This part suggests that the barrier to change is the social construction of everyday life, which defines the roles that citizens play within their communities and, in turn, the duties owed to others. ${ }^{134}$ This part asserts that liberalism has significant normative influence within this social construction of reality and is largely to blame.

This article started with a reflection upon the English Civil War because it was the first clear-spoken harbinger for the birth of the modern state. ${ }^{135}$ From the beginning, liberal ideas were in the cradle with the modern state. ${ }^{136}$ In the Western mind, liberal ideas (that is, thoughts about freedom in society) have always framed political debate over: (1) the degree modern government ought to interfere with its citizens to ensure social order (that is, the proper exercise of imperium) and (2) the degree of responsibility citizens ought to bear for the well-being of their neighbours (that is, the proper exercise of dominium). ${ }^{137}$

At the time of the English Civil War, King Charles I and the rationale of the divine right of kings were the obvious threat to freedom (that is, imperium). Today, power has evolved, and dominium now poses a significant threat to freedom as well. Liberalism, however, is stuck in the past, blinded to the social change it helped author, focusing upon the threat of imperium as though dominium were not a serious threat to

127 Kuykendall, supra note 113 at 541.

128 Roberts, supra note 98 at 259-261.

129 See Kuykendall, supra note 113; see also Kenneth Roth, “Corporate Social Responsibility,” Human Rights Watch (27 July 2000), online: <www.hrw.org/news/2000/07/27/corporate-social-responsibility>.

130 See Roberts, supra note 98; Oleg V Petrenko et al, "Corporate Social Responsibility or CEO Narcissism? CSR Motivations and Organizational Performance" (2016) 37 Strategic Management Journal 262.

131 See Joel Bakan, The Corporation: The Pathological Pursuit of Profit and Power (New York: Free Press, 2005).

132 Ibid.

133 Roberts, supra note 98 at 252.

134 See Freeden, supra note 37; Rosenblatt, supra note 42; Harvey, supra note 49. More broadly, see Peter L Berger \& Thomas Luckmann, The Social Construction of Reality: A Treatise in the Sociology of Knowledge, 2nd ed (London: Penguin, 1991).

135 Skinner, supra note 7 at $1-16$.

136 Ibid.

137 Ibid; Pettit, Republicanism, supra note 17 at 31-36; Tully, Public Philosophy, supra note 11 at 36. 
freedom too. ${ }^{138}$ Liberalism's blindness may be wilful. Protecting freedom is relatively uncomplicated when the central threat is assumed to be imperium; limiting government action increases freedom. ${ }^{139}$ However, when the threat to freedom includes dominium, freedom ideology's task is much more difficult. ${ }^{140}$ Whose freedom ought to prevail and to what degree? This issue is highly contested, ${ }^{141}$ especially in an era that values pluralism. ${ }^{142}$

What precisely is liberalism? The answer is less than straightforward. Liberalism has been a contested notion since its inception, which is not surprising considering the stakes. ${ }^{143}$ And yet it is so ubiquitous to the Western worldview that its massive impact upon the construction of self and society is largely obscured. ${ }^{144}$ Some commenters have even pronounced its "death." ${ }^{145}$ A parable by David Foster Wallace helps explain the mistake that the authors of such a pronouncement make:

There are these two young fish swimming along, and they happen to meet an older fish swimming the other way, who nods at them and says, 'Morning, boys. How's the water?' And the two young fish swim on for a bit, and then eventually one of them looks at the other and goes, 'What the hell is water?'146

Liberalism is like the water for citizens in Western societies. Hidden in the plain sight of everyday life, it forms the basic code for the modern world, ${ }^{147}$ constructing the core of the "common sense reality" of being a citizen and participating in social life. ${ }^{148}$ The historian Helena Rosenblatt details how the term has been used "in all sorts of different ways" throughout time. ${ }^{149}$ She notes that the "available histories of liberalism are seldom helpful" since their authors often assert a definition of liberalism with a vested bias, then proceed to "construct a history that supports it." 150

Political theorists tend to agree. The sociologist and political scientist, Colin Crouch, denounces liberalism as "about as slippery as a political term can be." "W1 While the political theorist Michael Freeden observes that "there is no single, unambiguous thing called liberalism" and that those espousing one definitive form of liberalism are cherry-picking items from the "crowded liberal repertoire" to the exclusion of others. ${ }^{152}$ Freeden provides an account of liberalism as a tradition of thought that has "at least five different historical layers." 153 This layering method to understanding liberalism is very useful since

138 See e.g. Isaiah Berlin, Liberty: Incorporating Four Essays on Liberty (Oxford: Oxford University Press, 2002) at 207; see also Freeden, supra note 37; Rosenblatt, supra note 42.

139 Berlin, supra note 138 at 207.

140 Ibid.

141 Rosenblatt, supra note 42 at 1-2.

142 Freeden, supra note 37 at 47.

143 Rosenblatt, supra note 42 at 1; Skinner, supra note 7 at 1-16.

144 See Freeden, supra note 37 at 1; Harvey, supra note 49 at 23.

145 See e.g. R Emmett Tyrrell, The Death of Liberalism (Nashville: Thomas Nelson, 2012).

146 Jenna Krajeski, “This Is Water,” The New Yorker (19 September 2008), online: <www.newyorker.com/books/pageturner/this-is-water>.

147 Graf Peter Callies \& Peer Zumbansen, Rough Consensus and Running Code: A Theory of Transnational Private Law (Oxford: Hart Publishing, 2010) at 1-3.

148 Berger \& Luckmann, supra note 134 at 33; see also Harvey, supra note 49 at 29.

149 Rosenblatt, supra note 42 at $1-2$.

150 Ibid.

151 Colin Crouch, The Strange Non-Death of Neoliberalism (Cambridge, UK: Polity Press 2011) at 3.

152 Freeden, supra note 37 at 1.

153 Ibid at 37. 
it embraces the contradictions the term unavoidably presents. ${ }^{154}$ Freeden's "bottom" layer asserts a noninterference doctrine, which restricts the capacity of the governing authority (that is, the sovereign) to exercise power arbitrarily upon its citizens. ${ }^{155}$ The second layer declares that the sovereign is the "guarantor of private initiatives" (that is, it must observe the private rights that flow from ownership and contract), providing the basis for "social and national flourishing" through economic development. ${ }^{156}$ The third layer expands the scope of liberty, asserting that the sovereign must respect the autonomy necessary for developing individuality, broadening the scope of protected freedoms from merely "commercial exchange" to those associated with advancing human capacity such as freedom of speech and conscience. ${ }^{157}$ Or, as John Milton put it, "the liberty to know, to utter, to argue freely according to conscience." 158

The fourth layer marks a distinct break from the first three layers. English progressives, who were horrified by conditions of workers in the nineteenth century, flip the notion of liberty as being associated with things the sovereign must refrain from doing (that is, negative liberty) to a liberty associated with things the sovereign must grant from its largesse to ensure a minimum standard of living for all citizens to be freed from the chains of poverty (that is, positive liberty). ${ }^{159}$ They argued that such minimum standards (for example, food, water, shelter, access to medical care, and a modicum of education) are the minimum requisites for each individual to have a chance to flourish. ${ }^{160}$ Freeden notes that this layer of liberalism developed into the "ideological foundation of the welfare state."161

Freeden's final layer acknowledges the potential plurality of being, ${ }^{162}$ rejecting a common tacit claim of the other four layers: that liberalism represents a superior normative position to others. ${ }^{163}$ An extreme logical extension might insist that liberals surrender their "rationalist and universalist tradition," forfeiting the claim that principled decision-making has primacy and recognizing that any other claim is always on equal footing with their version of liberalism. ${ }^{164}$ A more moderate extension might assert that all requests to be recognized as one wants - within contestable limits - ought to have a legitimate claim to a position of "influence" within the "politics of identity" (that is, to be recognized in a way that empowers one to be free to be true to one's self openly and without negative consequences within the public sphere). ${ }^{165}$

Freeden is first to acknowledge that his five layers interact in a "constant state of mutual rearrangement." 166 They do not "constitute a neat sequential chain" and are "linked, if at all, in ill-fitting and patchy continuities," which "do not add up into a unified whole" since they "too often pull in

154 Crouch, supra note 152 at 3.

155 Freeden, supra note 37 at 40.

156 Ibid at 42.

157 Ibid at 45.

158 John Milton, “Areopagitica” (1644), Dartmouth College, online: $<$ https://www.dartmouth.edu/ milton/reading_room/areopagitica/text.html $>$.

159 Freeden, supra note 37 at 47.

160 Ibid.

161 Ibid.

162 See generally James Tully, "Recognition and Dialogue: The Emergence of a New Field" (2004) 7 Critical Rev Intl Social \& Political Philosophy 84; Charles Taylor, "The Politics of Recognition" in Amy Gutmann, ed, Multiculturalism: Examining the Politics of Recognition (Princeton, NJ: Princeton University Press, 1994) 25.

163 Freeden, supra note 37 at 50.

164 John Gray, “Agonistic Liberalism” (1995) 12 Social Philosophy \& Policy 111 at 114.

165 Freeden, supra note 37 at 50.

166 Ibid at 37. 
irreconcilable directions."167 Thus, Freeden's interpretation of liberalism does not provide a concise definition, modestly offering a measure to distinguish a form of liberalism from something other.

Both Rosenblatt ${ }^{168}$ and Crouch ${ }^{169}$ would likely approve of this approach. Rosenblatt persuasively argues that the history of liberalism started with the fight to remove the "aristocratic impediments that kept wealth, power and opportunity in the hands of a hereditary elite" and then the fight to remove that which it created: "plutocracy and the exploitation that accompanied it." ${ }^{170}$ Rosenblatt argues that until liberalism's "turn to the right" in the twentieth century, ${ }^{171}$ its legacy was the promotion of "civic values," human potential, and the "public good." ${ }^{772}$ She points to Isaiah Berlin as a key figure in this conservative turn, ${ }^{173}$ suggesting that Berlin filtered John Locke's writings to his own ends, transforming Locke into the "founding father" of Berlin's interpretation of liberalism. ${ }^{174}$

Berlin's thought does much to transform the notion of liberty in the modern mind, providing a fair reflection of mainstream liberalism today. ${ }^{175}$ Berlin argued that two forms of liberty exist: positive and negative. Positive liberty is a form of "self-mastery" over the lower nature: the liberation from "spiritual slavery" in which one's higher nature "dominates" one's lower nature, so that it is "brought to heel." Berlin continues that this form of liberty allows for the practice of self-mastery but only superficially. Informed by Cold War politics, he explains how an authoritarian government can use positive liberty as a tool of domination by defining the higher nature in terms of "something wider than the individual" (for example, a social ideal). ${ }^{177}$ The result is a perverse form of liberty, which can be used "to justify the coercion of some men by others in order to raise them to a higher level of freedom," and, if they do not pursue this goal themselves, they are considered "blind or ignorant or corrupt" and punished accordingly. ${ }^{178}$ With this, Berlin dismisses positive liberty as not a form of liberty at all. Upon reflection, it is worth noting that Freeden's interpretation of liberalism - in particular, his fourth layer - suggests that Berlin's interpretation of positive liberty is to some degree problematic. ${ }^{179}$

For Berlin, liberalism's formula for securing true liberty (that is, negative liberty) is to allow "the maximum degree of non-interference compatible with the minimum demands of social life." 180 As to what the minimum demands might be, Berlin adds that the "bulk of humanity" has always been "prepared to sacrifice" some freedom for "security, status, prosperity, power ... and many other values that appear wholly, or in part, incompatible with the attainment of the greatest degree of individual liberty." ${ }^{181}$ Berlin also strongly defends value pluralism, asserting that incommensurable values should not "be graded on one scale," warning that if government attempts to use its brand of moral decision-making as "a slide-

167 Ibid.

168 Rosenblatt, supra note 42 at $1-2$.

169 Crouch, supra note 152 at 3.

170 Rosenblatt, supra note 42 at 266.

171 Ibid at 271 .

172 Ibid at 266.

173 Ibid at 272.

174 Ibid.

175 See Bruce Baum \& Robert Nickels, "Introduction" in Bruce Baum \& Robert Nickels, eds, Isaiah Berlin and the Politics of Freedom: "Two Concepts of Liberty" 50 Years Later (New York: Routledge, 2013) 1 at 1-2 [Baum \& Nickels]. See also Berlin, supra note 138.

176 Berlin, supra note 138 at 179.

177 Ibid.; see also Baum \& Nickels, supra note 176 at $1-3$.

178 Ibid.

179 See Freeden, supra note 37 at 47.

180 Berlin, supra note 138 at 207.

181 Ibid. 
rule," such action constitutes a "self-deceit" or a "deliberate hypocrisy" and certainly an unjustified infringement of freedom. ${ }^{182}$ Moreover, he recommends that liberals ought to step back, granting people the freedom that "makes them human" (that is, "their being and thought and sense of their own identity"). ${ }^{183}$

Berlin's liberal theory represents the core of mainstream liberalism today. ${ }^{184}$ It asserts that the fourth layer of liberalism, which supported the welfare state ideology, ought to be rejected as antithetical to a true understanding of liberalism. ${ }^{185}$ It also recommends that anything more than a limited exercise of imperium is an unjustified infringement upon individual freedom. ${ }^{186}$ In particular, it teaches that governments ought to remove themselves from private disputes, allowing citizens to resolve them for themselves, respecting value pluralism. ${ }^{187}$

The line between neo-liberalism and liberalism's turn to the right is at best blurred and at worst indistinguishable. Some might call Berlin's liberalism a form of neo-liberalism or a close relative, ${ }^{188}$ but others would not. ${ }^{189}$ Freeden contends that neo-liberalism is "one of the most prominent misappropriations of liberalism." 190 To Freeden, neo-liberalism retains the liberal concept of employing rationality to maximize "economic advantage" but ignores the remainder of liberalism's potential. ${ }^{191}$ Berlin's liberalism is not so limited in scope. ${ }^{192}$ That said, neo-liberals would not agree with Freeden's characterization either. ${ }^{193}$ Whether neo-liberal or not, Berlin's stance reflects liberalism's turn to the right, which has been sustained to the present (that is, at least in the Anglo-American world). ${ }^{194}$

Mainstream liberalism sells the idea that when government is removed from society, what remains is freedom and the better possibility of the good life. As Pettit notes, mainstream liberalism clearly communicates that "people only have freedom in the silence of the law; they have freedom only where law does not intrude." 195 For instance, Hayek - who is a liberal by Freeden's measure ${ }^{196}$ but definitely on the more conservative side - envisions that when the agents of imperium are removed from society, institutions "arise" and function "without a designing and directing mind." 197 For Hayek, citizens need little government involvement since citizens have the best chance to flourish through "spontaneous" social interactions sans interference. ${ }^{198}$ All people need to thrive is a "licence to experiment." 199 Defending this free space for flourishing and experiment, he asserts that the actions of a citizen are coercive only if said citizen has a monopoly position over a good or service and if such good or service is essential to another

182 Ibid at 216.

183 Ibid at 217.

184 Rosenblatt, supra note 42 at 266-272.

185 Berlin, supra note 138 at 207.

186 Ibid at 179.

187 Ibid at 217.

188 Rosenblatt, supra note 42 at 272.

189 Freeden, supra note 37 at 109.

190 Ibid.

191 Ibid.

192 Berlin, supra note 138 at 207.

193 See Jeremy Shearmur, "In Defense of Neoliberalism" (1992) 3 J Democracy 75.

194 Ibid at 272.

195 Pettit, Republicanism, supra note 17 at 37.

196 Freeden, supra note 37 at 90-91.

197 Friedrich A Hayek, Individualism and Economic Order (Chicago: University of Chicago Press, 1948 ) at 6-7.

198 FA von Hayek, The Constitution of Liberty (Chicago: University of Chicago Press, 1960) at 12-16, 63 [Hayek, Constitution of Liberty].

199 Friedrich A Hayek, Law, Legislation, and Liberty, volume 3: The Political Order of a Free People (Chicago: University of Chicago Press, 1979) at 204. 
citizen's existence. ${ }^{200} \mathrm{He}$ opines that otherwise "the conditions" a citizen "exacts" upon another citizen for rendering services cannot be a form of coercion. ${ }^{201}$ Thus, government interference is unjustified within such consensual private transactions. ${ }^{202}$

Mainstream liberalism, like Hayek's version, takes a very narrow view of the dangers of private power, holding that coercion only exists in monopoly situations. However, many examples question this position. For instance, criminal law, contract law and tort law often struggle with coercive transactions outside of monopoly. ${ }^{203}$ Yet liberalism ensures that such notions of negative liberty remain firmly embedded within the social construction of reality. ${ }^{204}$ This normativity directs citizens to avoid a critical engagement with the struggle to balance rights, ${ }^{205}$ inviting shortcuts to certainty, ${ }^{206}$ which undermines learning, ${ }^{207}$ and helps to preserve the inequalities of modern society. ${ }^{208}$

Mainstream liberalism success can be attributed to the influence of two messages that it consistently communicates through the general noise of contestation that follows it. ${ }^{209}$ First, when an agent of imperium interferes with a citizen - whether it is justified or not - it constitutes an infringement upon individual freedom. ${ }^{210}$ Second, when a citizen is harmed by another citizen, either the harm was justified (for example, the harmed party consented to it) ${ }^{211}$ or the government failed to prevent (or provide an avenue to seek compensation for) the harm, ${ }^{212}$ which was opined to be unjustified. ${ }^{213}$ Between the two claims, dominium always seems to slip from mainstream liberalism's detection, dodging focus ... and also responsibility.

This ideology provides fruitful ground for protecting a broad exercise of dominium. For instance, when a business actor lobbies a government to sustain or change a policy, this messaging can play a part, offering a foundation for reasoning to discourage government interference. Some examples include: (1) people must be free to enforce the conditions that their contracts exact and (2) when government does not interfere

200 Hayek, Constitution of Liberty, supra note 199 at 136.

201 Ibid.

202 Ibid.

203 See Christopher Kutz, "Responsibility" in Jules Coleman \& Scott Shapiro, eds, The Oxford Handbook of Jurisprudences and Philosophy of Law (Oxford: Oxford University Press, 2004) 548; see also Jesse Wall, "Public Wrongs and Private Wrongs" (2018) 35 Can JL \& Jur 177; RA Duff, “Toward a Modest Legal Moralism” (2014) 8 Crim L \& Philosophy 217; Nicola Lacey, "In Search of the Responsible Subject: History, Philosophy and Social Sciences in Criminal Law Theory" (2001) Mod L Rev 350.

204 Harvey, supra note 49 at 29.

205 See Jeremy Waldron, "Legal and Political Philosophy" in Coleman \& Shapiro, supra note 205, 352.

206 Robert E Denton Jr, "The Rhetorical Functions of Slogans: Classifications and Characteristics" (1980) 28

Communication Q 10 at 13-17; see also Nicolette Makovicky, Anne-Christine Trémon \& Sheyla S. Zandonai, "Slogans: Circulations, Contestations, and Current Engagements with Neoliberal Policies" in Nicolette Makovicky, Anne-Christine Trémon \& Sheyla S Zandonai, eds, Slogans: Subjection, Subversion, and the Politics of Neoliberalism (New York: Routledge, 2019) 1 at 1-23.

207 John Dewey explained that people experience reality as balancing between equilibrium and disequilibrium within a constantly change environment. See John Dewey, Art As Experience (New York: Capricorn Books, 1934) at 14.

208 See e.g. Hayek, Constitution of Liberty, supra note 199 at 136.

209 Freeden, supra note 37 at 37-49, Rosenblatt, supra note 42 at 1-2; Crouch, supra note 151 at 3.

210 Berlin, supra note 138 at 207, 215.

211 Pettit, Republicanism, supra note 17 at 165.

212 Kaldor-Hicks efficiency discounts the harm done to others by dominium as long as the harmed party is fully compensated for the loss. See John Hicks, "The Foundations of Welfare Economics" (1939) 49 Economic J 696 [Hicks]; Nicholas Kaldor, "Welfare Propositions in Economics and Interpersonal Comparisons of Utility" (1939) 49 Economic J 549 [Kaldor]; but see T de Scitovszky, “A Note on Welfare Propositions in Economics” (1941) 9 Rev Economic Studies 44.

213 Berlin, supra note 138 at 207, 215. 
with market competition, it produces optimal results for society. On the other hand, when a business' actions cause harm, this messaging also can play a part by encouraging moral distance. Some examples include: (1) if a legally sanctioned action proves to be harmful, government is to blame for not preventing or mitigating the harm; (2) parties claiming to be harmed are not, if they contractually accepted the risk of the harm; and (3) parties claiming to be harmed were not, if they were financially compensated. In these ways, mainstream liberalism supports arguments that restrict the exercise of imperium, while condoning a broad exercise of dominium. Without a sense of irony, or hypocrisy, this one-two punch provides a powerful blow to CSR, sustaining moral distance while minimizing government intervention.

\section{CIVIC REPUBLICANISM AND ITS APPROXIMATION TO LIBERALISM}

Pettit insists that civic republicanism is distinct from mainstream liberalism and unique within the tradition of liberal thought. ${ }^{214}$ While mainstream liberalism is more or less singularly focused on government interference, ${ }^{215}$ civic republicanism is focused on dominium as well. ${ }^{216}$ Both are seen as potential threats to freedom. ${ }^{217}$ As argued in the last section, the importance of this distinction is that ignoring dominium helps citizens sustain their moral distance, which can erode integrity, undermine the effectiveness of CSR, and lead to governance failure. ${ }^{218}$

Thus, mainstream liberalism's simplification of freedom comes at a high price. For instance, assume I am contemplating whether to exercise my dominium in a manner that benefits me but that will harm others. Assume that no legal recourse exists to acknowledge the harm I cause, to penalize me for causing it, or to compensate those I harm. Let say I install a coal furnace in my house, choose with my partner to have a dozen children, and hire a nanny to take care of them at the minimum legal wage though I could afford to pay her more. ${ }^{219}$

The only thing between the way I exercise my power and those vulnerable to my exercise of power is my conscience. Will I harm the other? If I am looking for an excuse to not spoil "the plans" I have for my "own enjoyment" at the expense of others, ${ }^{220}$ mainstream liberalism will accommodate. I ask myself: is it against the law to do what I am doing? I answer: no. As per the furnace, I pay a carbon price on the coal, so I follow the law and do my part. Moreover, there is no law against having a dozen children. We love them, and can easily afford to raise them. Besides, Canada's population is aging and needs to expand. Finally, the nanny really needed the job. She agreed to the wage and appears happy. The government sets the minimum wage, if it wasn't enough, they would raise it.

Mainstream liberalism suggests that I need not go much further, helping me to hide my dominium from myself, whispering that the collateral damage is a function of my liberty and resting my conscience. Liberalism has provided me with a shortcut to abdicating my responsibility to my neighbour, allowing me

\section{Ibid at 19.}

Ibid.

Pettit, Republicanism, supra note 17 at 31-35.

Ibid.

218 Roberts, supra note 98 at 251-252.

219 You, my reader, may protest that one or more examples are ethical activities. However, each contribute to problems (economic inequality, climate change and population growth). Each causes harm to others. The point is that the cumulative effect of the daily choices of citizens are just as dangerous as the monoliths of our imagination. It is not only big business that wields dominium. The high cost of liberalism is that it helps hide serious consideration of such issues.

220 Ibid. 
to have a sense of self and citizenship in which I can always be a victim of interference and, as long as I comply with the law, rest assured that my actions are justified. ${ }^{221}$

Civic republicanism accommodates no such indulgences. It demands that I acknowledge the exercise of my own dominium, and account for the consequences of my actions. Am I engaging in moral distance strategies? Am I harming future generations by recklessly contributing to the climate change or population crisis?222 Does my nanny's consent justify the fact that I do not pay her a living wage? If I am harming them, do they have a recourse to protect themselves? If I am using my dominium to harm these parties and they have no recourse to stop me, a civic republican might deem one or more of these actions to constitute a form of domination and thus a violation of freedom. ${ }^{223}$ From this perspective, liberalism's well-worn path to abdicating personal responsibility is blocked and my moral distance, if not removed, is seriously challenged. ${ }^{224}$

To be honest, my hypothetical self is not so sure he likes civic republicanism. It does not feel like my freedom is being protected any longer. Mainstream liberalism never asked anything of me except to hold government to account and mind my own business, arming me with moral distance and freedom from interference. Civic republicanism narrows my scope of options, and I am not so comfortable with this. On the other hand, it makes me think about the consequences of my actions in a manner that liberalism never forced me to do. It also, in theory, better protects me from the threat of domination that others pose. It promises a different kind of freedom.

In sum, civic republicanism demands self-reflection, which challenges us to surrender our moral distance, acknowledge the harm we cause, and take responsibility for it. Thus, civic republicanism makes freedom ideology more complex and possibly less attractive for some who enjoy the privileges associated with their current understanding of freedom.

Civic republicanism is a freedom theory that promotes personal accountability for dominium. Moreover, it also advocates for "good laws" as safeguards against the failure to inspire such accountability (that is, the failure of integrity). ${ }^{225}$ Good laws are the non-arbitrary exercise of imperium to prevent the arbitrary exercise of dominium. ${ }^{226}$ Civic republicanism is distinct from mainstream liberalism. ${ }^{227}$ As suggested in Part IV, Berlin's liberalism is a fair proxy for mainstream liberalism today. ${ }^{228}$ Berlin's liberalism is based on the theory of negative liberty, which promotes a freedom that helps citizens to achieve the ideal of non-interference but will begrudgingly sacrifice that ideal to promote other justifiable

221 Sandel argues that liberalism promotes an improvished sense of citizenship and community, which promotes selfishness. See Michael J. Sandel, Liberalism and its Critics (New York, NY: NYU Press, 1984) at 5-7.

222 Our World in Data, World Population by Region, online: <https://ourworldindata.org/grapher/world-population-byworld-regions-post-1820>.

223 Pettit, Republicanism, supra note 17 at 21-22, 55.

224 Roberts, supra note 98 at 251-252. But also Berger \& Luckmann, supra note 134 at 33; and Harvey, supra note 49 at 29.

225 Pettit, Republicanism, supra note 17 at 36.

226 Ibid at 31-35.

227 Ibid at 22.

228 Rosenblatt, supra note 42 at 272. 
ends in specific cases. ${ }^{229}$ Pettit calls negative liberty "freedom as non-interference." ${ }^{230}$ Civic republicanism defines freedom differently (that is, as non-domination). ${ }^{231}$

To Pettit, non-domination occurs when "social design" (for example, legal and non-legal mechanisms) ensures that "no other has the capacity to interfere on an arbitrary basis in [another's] choices." ${ }^{232}$ In other words, such social design employs safeguards that provide each of us the power to fend off arbitrary interference. ${ }^{233}$ Pettit explains arbitrary interference as follows:

An act is perpetrated on an arbitrary basis, we can say, if it is subject just to the arbitrium, the decision or judgement, of the agent; the agent was in a position to choose it or not choose it, at their pleasure. When we say that an act of interference is perpetrated on an arbitrary basis, then, we imply that like any arbitrary act it is chosen at the agent's pleasure. And in particular, since interference with others is involved, we imply that it is chosen or rejected without reference to the interests, or the opinions, of those affected. ... An act is arbitrary, in this usage, by virtue of the controls - specifically, the lack of controls - under which it materializes, not by virtue of the particular consequences to which it gives rise. ${ }^{234}$

The key take-away is that the arbitrary interference, from which civic republicanism attempts to protect others, is procedural in nature (that is, merely the capacity to interfere without any consequence) and not substantive (that is, actual interference). ${ }^{235}$ Thus, one need not "actually suffer interference at the hands of those who dominate them"; the capacity to interfere arbitrarily is enough. ${ }^{236}$ Upon reflection, a difference between mainstream liberalism and civic republicanism presents itself: liberalism does not regard "domination without interference" as a threat to freedom, while civic republicanism does. ${ }^{237}$

Pettit's explanation of the non-interfering master provides a clear example of domination without interference:

I may be dominated by another - without actually being interfered with in any of my choices. It may just happen that my master is of a kindly and non-interfering disposition. Or it may just happen that I am cunning or fawning enough to be able to get away with doing whatever I like. I suffer domination to the extent that I have a master; I enjoy noninterference to the extent that that master fails to interfere. ${ }^{238}$

But, of course, that master could have a change of heart, and Pettit-as-slave could lose favour. The point is that the threat of domination is ever present, and Pettit-as-slave must always live in fear of losing favour and make choices that help to ensure he does not. Just being subject to the most "kindly and noninterfering" person, who nonetheless has the capacity to interfere arbitrarily in Pettit's life, is enough to

229 Berlin, supra note 138 at 207

230 Pettit, Republicanism, supra note 17 at 21.

231 Ibid at 22.

232 Ibid at 67.

233 Ibid. Such safeguards might call to mind the safeguards of Cohen's "interest based" platform. See Cohen, "Dispute Systems Design," supra note 35 at 62.

234 Pettit, Republicanism, supra note 17 at 55.

235 Ibid.

236 Martí \& Pettit, supra note 17 at 33.

237 Pettit, Republicanism, supra note 17 at 23.

238 Ibid at 22-23. 
rob him of his liberty. ${ }^{239}$ Pettit-as-slave is still a slave; he is still dominated; he is not free. Even if Pettit's master never interfered with him until his death, Pettit was never free; he had to live with the threat of interference without recourse for his entire life.

Pettit's distinction between domination and interference has more layers. ${ }^{240}$ His above example of the master-slave relationship suggests that domination occurs when the "only brake on the interference" is the interferer's "unchecked judgement." 241 Thus, domination could be considered a subset of interference.

Another kind of interference exists since it can also be non-arbitrary (that is, rules are in place to ensure that a "brake" other than the interferer's "unchecked judgement" is in place). ${ }^{242}$ Properly designed interference can be used to safeguard against domination, or as Pettit puts it, to place citizens "in a position where no one can interfere arbitrarily in [their] affairs ... from the moment that the institutions are in place." ${ }^{243}$ Identifying domination can be difficult. Pettit explains how domination may be more or less invisible to parties who are not privy to the power dynamic:

The powerless are not going to be able to look the powerful in the eye, conscious as each will be - and conscious as each will be of the other's consciousness - of this asymmetry. Both will share an awareness that the powerless can do nothing except by the leave of the powerful: that the powerless are at the mercy of the powerful and not on equal terms. The master-slave scenario will materialize, and the asymmetry between the two sides will be a communicative as well as an objective reality. ${ }^{244}$

Thus, the domination may never be spotted by a third party to the relationship. The "power-victim" may be hiding in plain sight, enduring a "psychological status" of being less than equal. ${ }^{245}$ Accordingly, the task of identifying domination can be more difficult than one might first assume.

Regulatory architects must be vigilant to prevent arbitrary interference. ${ }^{246}$ They must identify where opportunities for domination may be hiding in society, then construct institutional design that offers recourse to power victims (that is, avenues to extract one's self from, or to avoid being at the mercy of, the powerful). In other words, such architects must construct and place legal tools in the social spaces where citizens are likely to fall victim to domination. ${ }^{247}$

In sum, civic republicanism asserts that non-domination cannot be ensured without the "presence of protective institutions" in society "that can testify" and assure citizens that "intersubjective equality" is, and will be, present in their daily lives. ${ }^{248}$ Pettit reflects that providing such a psychological status of freedom is "a very dense and demanding goal around which to orientate our social and political institutions" but that modern society is "well up to the task of realizing such an ideal."249

Civic republicanism endorses elements of all five layers of Freeden's liberalism. However, it moves beyond them, reframing the calculus for protecting freedom in modern society, attacking moral distance,

Ibid at 22 .

Ibid at 22-25.

Ibid.

Ibid.

Ibid at 107.

Ibid at 60-61.

Ibid at 63-64.

Ibid at 55, 60-64.

Sukdeo, supra note 31 at 59.

Pettit, Republicanism, supra note 17 at 72.

Ibid at 47-48. 
spoiling our more selfish plans for enjoyment, and, ultimately, promoting integrity within governance. It also endorses an institutional design that enforces such integrity. Civic republicanism arguably represents the pinnacle of freedom ideology to date, providing us with the best opportunity available to meet the governance challenges of our time.

Upon reflection, civic republicanism and mainstream liberalism have a much different understanding of freedom. For liberalism, when imperium's agents interfere with citizens, it always comes at the cost to freedom. Moreover, it concludes that dominium is rarely coercive, so when government is removed from the equation, freedom flourishes. For civic republicanism, imperium and dominium both tend to be corrosive to freedom. Non-arbitrary interference is required to protect the powerless from the powerful. Thus, as Pettit notes, freedom always is "a status that exists only under a suitable legal regime." ${ }^{250}$ When Pettit uses the language "suitable legal regime," he most certainly includes a broad notion of law that includes CSR's support of good social design. ${ }^{251}$

CSR should adopt civic republicanism as a normative guide in its work. It is a better fit than mainstream liberalism - and liberalism, more generally - opening new conceptual opportunities for CSR to devise strategies to meet its ends.

\section{FORTIFYING CSR}

Milton Friedman was another champion and architect of liberalism's turn to the right, spreading the message that, if governments would just stop interfering with markets and society, everyone would be far better off. ${ }^{252}$ In 1970, Friedman infamously declared in a New York Times op-ed that "there is one and only one social responsibility of business" - "to increase its profits so long as it stays within the rules of the game, which is to say, engages in open and free competition without deception or fraud." ${ }^{253}$ Friedman drove home the message that the market did a better job at regulating society than governments and that governments needed to privatize services and deregulate business activities if society was to progress. $^{254}$ If government would only unleash the "Power of the Market," the result would be greater prosperity and freedom for all. ${ }^{255}$ His message remains a prime example of how mainstream liberal ideas sustain moral distance.

Friedman's call does little more than promote what Roberts would call a "single minded pursuit of economic efficiency." 256 It is clearly antithetical to any interpretation of social responsibility that CSR endorses. $^{257}$ And, yet, CSR has been guilty of supporting variations of Friedman's deregulatory politics time and again. ${ }^{258}$ Ford has uncovered one possible reason for this ironic pattern of behaviour within CSR; after extensive study of progressive regulatory scholarship, she reports that many of these scholars were too eager to find consensus between themselves and scholars like Friedman on the issues of

250 Ibid.

251 Ibid at 67, 107.

252 Milton Friedman, “The Social Responsibility of Business is to Increase its Profits," New York Times (13 September 1970) [Friedman, "Social Responsibility"]; Milton Friedman \& Rose Friedman, Free to Choose: A Personal Statement (New York: Harcourt, 1980); Milton Friedman, "Free Markets and Free Speech" (1987) 10 Harv JL \& Pub Pol'y 1

[Friedman, "Free Markets"].

253 Friedman, "Social Responsibility," Ibid.

254 Friedman \& Friedman, supra note 252 at 1-8.

255 Ibid at 9-37; Friedman, "Free Markets," supra note 252.

256 Roberts, supra note 98 at 255.

257 Ibid.

258 For more on deregulatory politics, see Bratton, supra note 33; Stewart, "Behind the Cloak," supra note 61 at 263.

258 Ford, supra note 18 at 101-102. 
"decentralization, self-regulation, and knocking down rigid pre-existing regulatory apparatuses." ${ }^{259}$ She concludes that a "false consensus" can be found in the literature, in which these scholars ignored the "crucial distinction" between their ends and conservative liberal ideology, paving the way for a bipartisan endorsement of deregulation. ${ }^{260}$

Civic republicanism could have protected some from within CSR from making this miscalculation. Civic republicanism is aligned with the work of regulatory theorists such as Ford, who promote nonpaternalist, decentred, interest-based platforms for dispute resolution in society. ${ }^{261}$ Many progressive regulatory scholars, whose work Ford reviewed in her study, thought they were endorsing governance similar to her vision. ${ }^{262}$ However, they missed a critical component: the primacy of safeguarding against domination. ${ }^{263}$ They did not stress that such dispute resolution platforms must have safeguards, which guarantee that the powerful cannot dominate the powerless ${ }^{264}$ or, as Ford puts it, that guarantee "the playing field is level in multiple senses." 265

If these scholars had been advocates of civic republicanism, Pettit's central goal of protecting freedom as non-domination would have been in the forefront of their minds. It demands a critical assessment of the exercise of power. They would have had to ask themselves: are the vulnerable parties "in a position where no one can interfere arbitrarily" with their ability to use these platforms for dispute resolution freely? ${ }^{266}$ Without adequate safeguards to protect against the unfettered exercise of dominium, a civic republican would answer no. Although interference exists in degrees, this answer must be a confident yes before a civic republican would move forward.

If these scholars respected this central tenet of civic republicanism as a non-negotiable condition, the result would have been different. Conservative liberals would have revealed the perceived consensus for what it proved to be: "false." 267 To accept civic republicanism's condition is to ignore a foundational principal of mainstream liberalism: interference with the exercise of dominium infringes freedom. ${ }^{268}$ Here is where the two freedom ideologies would come to loggerheads. Again, conservative liberals assert that interference with the exercise of dominium infringes freedom, while civic republicans assert that such interference produces freedom. The ideologies are diametrically opposed, and the difference could not be ignored.

\section{Ibid at 127.}

Ibid.

261 See Ford, supra note 18; see also Levi-Faur, "From Big Governance," supra note 54; Levi-Faur, "Regulatory Capitalism," supra note 35; Cohen, "Dispute Systems Design," supra note 35 at 60; Cohen, "ADR and Some Thoughts," supra note 35 at $456-461$.

262 Ford, supra note 18 at 101-102, 127.

263 Ibid at 233.

264 Pettit, Republicanism, supra note 17 at 60-61.

265 Ford, supra note 18 at 233.

266 Ibid at 107.

267 For more on deregulatory politics, see Bratton, supra note 33; Stewart, "Behind the Cloak," supra note 61 at 263.

267 Ford, supra note 18 at $101-102$.

268 See e.g. Berlin, supra note 138; Hayek, Constitution of Liberty, supra note 199; Hayek, Road to Serfdom, supra note 38; Friedman \& Friedman, supra note 253; Friedman, "Social Responsibility," supra note 252; Friedman, "Free Markets," supra note 252. 
Pettit's theory guides governance theorists to accept that the use of non-arbitrary interference is a nonnegotiable requirement for freedom to flourish in modern society. ${ }^{269}$ Beyond this, how does civic republicanism speak to CSR? To start, it may not always be in CSR's corner. It is not ideologically narrow; it encourages a reassessment of all "established liberal views, whether of a left-of-center or right-of-center cast." ${ }^{270}$ For those fearful of government overreach, it asserts that state action cannot exercise imperium arbitrarily and that government be diligent to limit its interference; it can only interfere with citizens to protect against the abuse of power in society. ${ }^{271}$ For those wishing for greater substantive equality, it asserts that non-arbitrary interference is a prerequisite to prevent the arbitrary exercise of dominium. ${ }^{272}$ It challenges all who engage in debates on liberty to accept the assertion: when a society legitimates the domination of citizens by citizens, that society's status as free is in question. ${ }^{273}$

Thus, civic republicanism is an invitation for a spectrum of opinions as to the role of government, based on the precondition that a society should protect freedom as non-domination. More broadly, it is an invitation to imagine what a social design of such a free society might look like. One measure of success would be that the result is an "empire of laws" and not an "empire of men", 274 another would be that imperium protects a liberty that is "civil as distinct from natural freedom." ${ }^{275}$ In terms of what civic republicanism might mean for business, it is not opposed to free markets, nor does it suggest that markets cannot promote freedom. In fact, it strongly endorses the promotion of economic prosperity since, as Pettit argues, when employment is high and the financial system strong, then opportunities are removed "for people to be exploited and manipulated" and, thus, the "prospects for freedom as non-domination are improved."276

In addition, Pettit argues that markets can help protect against domination. He asserts:

It is true that in the free market, as theorized by economists, individuals face one another as the bearers of naked preferences and try each to do as well as they can in satisfying those preferences. But short of great differences of bargaining power, this arrangement does not mean that anyone is exposed to the possibility of arbitrary interference by any other or any group of others. One seller may be able to interfere with another by undercutting the other's price, but the second should be free, above the level of the competitive price, to undercut that price in turn; thus there is no question of permanent exposure to interference by another. The problems of majority preference formation that plague the political arena need not have analogues in the market. ${ }^{277}$

That said, the rationales for proper market function "may be quite different" than those that are "supported by other approaches." 278 In particular, the gains in terms of freedom achieved by promoting prosperity

\footnotetext{
269 Pettit, Republicanism, supra note 17 at 65, 60-61, 65, 163-165.

270 Martí \& Pettit, supra note 17 at 31.

271 Ibid at 52.

272 Pettit, Republicanism, supra note 17 at 55-67.

273 Ibid.

274 Harrington, supra note 24 at 20.

275 Pettit, Republicanism, supra note 17 at 66.

276 Ibid at 163.

277 Ibid at 205.

278 Ibid at 163.
} 
cannot be "offset by losses" resulting from the manner used to achieve them. ${ }^{279}$ One example of this would be allowing the Kaldor-Hicks justification to legitimate the harming of others in the pursuit of profit (that is, as long as one pays for the damage caused, the harm is justified). ${ }^{280}$

Another example is the darker side of the "doctrine of free contract."281 Morris Cohen argued that one "who is under economic necessity is not really free" and that without restrictions on the freedom to contract with those under such economic duress, few protections against "contracts of slavery" exist. ${ }^{282} \mathrm{~A}$ starving human will do most anything for food. Obviously, allowing the domination of one contracting party by the other as long as both parties agree to accept such treatment may promote prosperity, but the means are antithetical to the ultimate end of protecting freedom as non-domination.

Civic republicanism does not accept that domination is permissible as long as the consent to the contract was "not actively coerced." 283 This exception to freedom, Pettit opines, could never have been legitimated if legal thinkers had always focused upon preventing domination instead of "just the absence of interference." 284 Accordingly, civic republicanism would disallow "contracts that involve terms under which one party had the possibility of dominating others." ${ }^{" 285}$ Pettit declares:

[T] he free contract cannot serve the role of automatic legitimator - even prima facie legitimator - of what happens under the terms of the contract. The idea of free contract loses the authorizing capacity that it was given in the classical liberal tradition. ${ }^{286}$

Moreover, the exercise of imperium must ensure a market design that embeds "countervailing powers," which is a necessary prerequisite to removing the asymmetries that make contracts unfree. For instance, the law must provide creditor protections, the provision of adequate employment opportunities, the freedom to unionize, the option to strike, and other such compensation for inequalities in the marketplace. ${ }^{287}$ Civic republicanism asserts that such corrections are essential conditions of a truly free market since, without them, individuals live under economic conditions in which they will submit "voluntarily" to domination. ${ }^{288}$ Otherwise, the doctrine of free contract functions as a cynical manipulation of liberty.

\section{CONCLUSION}

CSR has been an instrumental force for innovation in modern regulation. However, for all of its achievements, it has been forced to operate without the full support of the modern state project, largely due to liberalism's long-standing influence over understandings of state practice. Civic republicanism provides fresh perspective on state practice, opening new opportunities for CSR's role within it. Freedom is always a product of intelligent institutional design, and by this measure CSR has been an innovative promoter of freedom, protecting the powerless from the powerful. However, mainstream liberalism has

279 Ibid at 164.

280 See Hicks, supra note 212; and Kaldor, supra note 212.

281 Pettit, Republicanism, supra note 17 at 62.

282 Morris R Cohen, “The Basis of Contract" (1933) 4 Harv L Rev 553 at 587.

283 Pettit, Republicanism, supra note 17 at 62.

284 Ibid at 164.

285 Ibid.

286 Ibid at 165.

287 Ibid at 61.

288 Ibid at 61, 142, 164. 
posed a hurdle to this progress toward freedom, informing how we construct our everyday lives, promoting a moral distance that shapes both governance practice and citizen behaviour today. Such embedded notions of freedom as non-interference offer one measure of the challenge facing CSR - and other institutional architects - if modern society is to live up to the promise of safeguarding freedom. 